\section{Relaying Telegrams}

THE General Post Office recently opened in London a new telegraphy relay centre, designed to speed up the transmission of overseas telegrams. As well as sending out cables which originate in the United Kingdom, the centre, at Cardinal House in Farringdon Street, will also handle the large quantities of telegrams which simply pass through London on their way from, say, Montreal to Sydney.

The new system is almost entirely automatic, but because automatic routing requires an extra line in the message - equal in length to 10 per cent of the average cable-provision is made for manual routing for telegraph administrations unwilling to pay extra. Messages arriving at Cardinal House are stored temporarily in ferrite stores and, if there is a suitable line available, are retransmitted immediately. If there is no line available, the messages are stored on magnetic tape to wait for a suitable line. The ferrite stores are small-2,000 characters-but the tape stores have a capacity of 40,000 characters each, and can if necessary accumulate messages over a period of hours if any outgoing line is out of action. Messages stored in this way are retransmitted in order of priority. The system replaces a much cruder arrangement at Electra House in which cables were punched out on tape, torn off manually and retransmitted on another machine.

The GPO is now looking forward to the ideal system - still ten years away--which would be automated from start to finish and controlled by computers. As well as routing the cables, the computer could also be used to work out the bills.

\section{More Fire-raising}

Fire Research 1966, published on October 17, is the annual report of the Joint Fire Research Organization of the Ministry of Technology and the Fire Offices' Committee. This partnership between government and insurance came into being for the purpose of carrying out research into all aspects of fire and the danger it represents to both life and property.

According to the report, the direct fire losses are of the order of $£ 75$ million a year, with a further $\mathfrak{E 7 5}$ million in indirect losses. In addition to this, the fire brigade service costs about another $\mathfrak{f 7 5}$ million. The size of fires has on an average decreased, but there are now considerably more of them.

The Fire Research Station, which costs $£ 300,000$ a year to run, carries out research and also undertakes a great deal of testing for industry, government and insurance. A study of the statistics of incendiarism suggests that more fires may be caused by arson than are reported, and, moreover, the cost of these fires is likely to be greater than for fires started by other means. Of the ten most recent fires estimated to have cost £l million each in direct fire loss, three have been attributed to incendiarism, six to unknown causes and one to smokers' requisites, as they are called.

The ratio of fire load to ventilation is an important factor in the extent of damage to structures and it is possible that the spread of fire in warehouses could be reduced or even prevented by providing water curtains. Smoke detectors have been found to give a much more rapid response than heat detectors, and there is evidence that a substantial reduction in fire losses could be made by the provision of efficient early warning systems.

A new method of protection has been developed in the chemistry and chemical engineering section for protecting industrial equipment which contains sparking components or flames. The method involves incorporation of flame arresters in the casing of equipment so that, if an explosion should occur in the casing, the pressure is relieved through vents but flame does not spread to the outside; this, it is hoped, may result in a saving of $f 250,000$ per annum.

\section{Parliament in Britain}

\section{Students}

THE Secretary of State for Education and Science, $\mathrm{Mr}$ P. Gordon Walker, gave the provisional number of full-time registered students in the universities of the United Kingdom on October 31, 1967, as 199,372, of whom 37,614 were new entrants to undergraduate and lower level courses. These figures compare with 184,510 and 54,058 respectively in the previous year. In addition, in Northern Ireland there were 5,230 students, including 1,489 new entrants, compared with 5,025 and 1,399 respectively in the previous year. (Written answer, November 16.)

\section{Machine Tools}

Mr A. Wedgwood Bens, the Minister of Technology, stated that the National Research Development Corporation was managing on behalf of the ministry a scheme intended to encourage the wider use of numerically controlled machine tools. The scheme enables suppliers to offer machine tools to customers on a sale or return basis. Twelve manufacturers were participating in the scheme and three marhine tools had been sold and delivered, with further sales in prospect. The scheme was capable of supporting sales to the value of $£ 3 \cdot 5-£ 4$ million, but the response from users had so far been very limited. Mr Benn also stated that the Ministry of Technology was helping to establish low-cost automation centres at universities and technical colleges throughout the UK. (Written answer, November 10.)

\section{Equipment Grants}

Baroness PhILlips said that the total amount of grant authorized for university expenditure on furniture and equipment in the current financial year was $£ 25.5$ million, and by July 1967 the universities

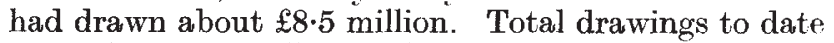
were about $\mathfrak{f 1 4}$ million. (Answer, November 16.)

\section{Research}

IN 1966-67 the Ministry of Technology spent $£ 238$ million on research and development in industry and within its own establishments. Dr Jeremy Bray, who gave the figures, said that the Government's policy was to place as many research and development contracts as possible in development areas, including Scotland. Total expenditure on research and development by the Ministry of Technology/Ministry of Aviation in 1966-67 was $£ 289$ million, of which $£ 53$ million was spent in the combined departments' establishments. Expenditure by industrial research associations in the financial year ending in 1966 was $£ 13.2$ million, and Government grants to the associa.

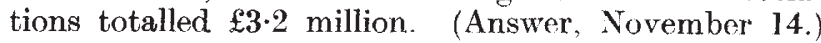

